\title{
* Battelle
}

Pacific Northwest Laboratories

Richland, Washington 99352

\section{AEC Research and Development Report}

NEPTUNIUM AND ZIRCONIUM EXTRACTION UNDER PUREX HA COLUMN SCRUB SECTION CONDITIONS

June 1971

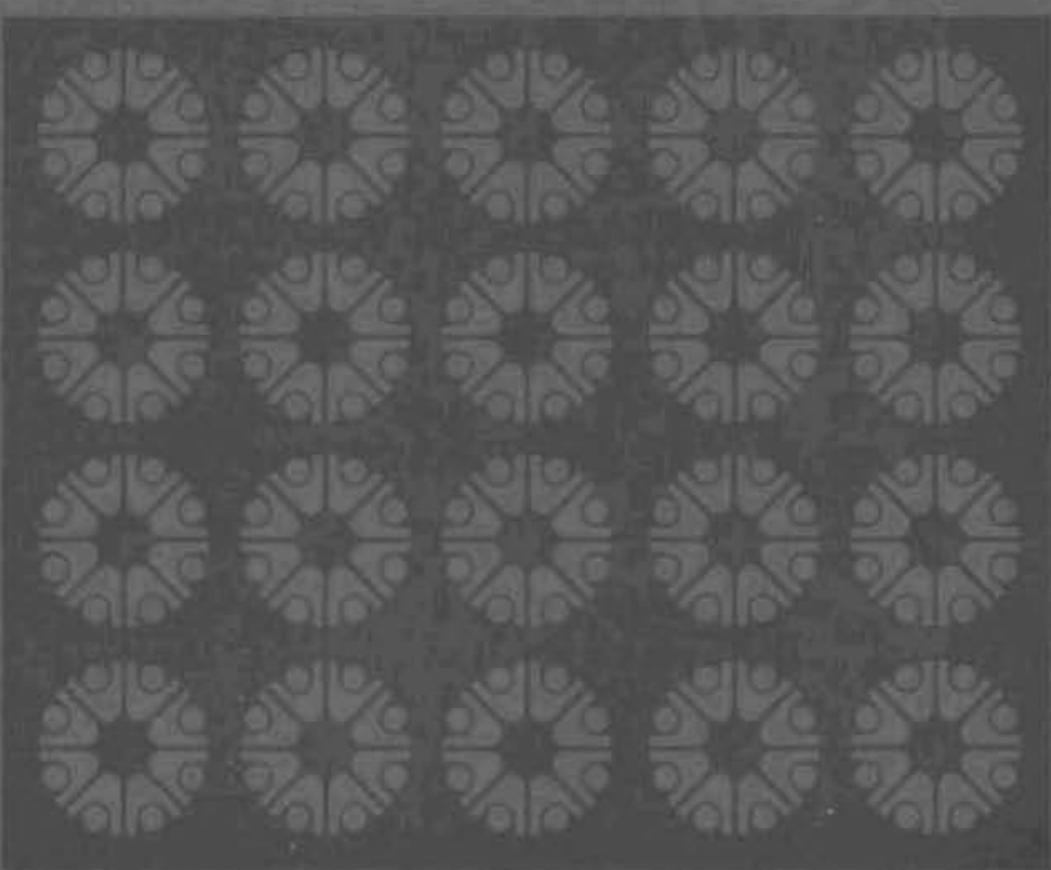




\title{
NOTICE
}

This repon was prepared as an account of work sponsored by the United States Covernment. Neither the United Srates nor the United States Aromic Energy Commission, nor any of their employees, makes any warzanty. express of implied, or assumes any legal fiability or responsibility for the accuracy. completeness or usefulness of any information, apparatis, product. or process disclosed, of represents that its use would not infringe ptivately-owned righth.

\author{
PACIFIC NORTHWBST LABORATORY \\ operated by \\ BATEIE \\ for the \\ US. ATOMIC ENERCV COMMISSION \\ Under Contract AItis-1)-1030
}




\title{
NEPTUNIUM AND ZIRCONIUM EXTRACTION UNDER
} PUREX HA COLUMN SCRUB SECTION CONDITIONS

\author{
By \\ J. L. Swans on \\ Chemistry Technology Department
}

June 1971

BATTELLE

PACIFIC NORTHWEST LABORATORIES

RICHLAND, WASHINGTON 99352 
Printed in the United States of America Available from

National Technical Information Service

U.S. Department of Commerce

5285 Port Royal Road

Springfield, Virginia 22151

Price: Printed Copy \$3.00; Microfiche $\$ 0.95$ 


\title{
NEPTUNIUM AND ZIRCONIUM EXTRACTION UNDER PUREX HA COLUMN SCRUB SECTION CONDITIONS
}

J. L. Swanson

\begin{abstract}
Distribution coefficients of zirconium and neptunium were measured to define conditions for increasing neptunium recovery while maintaining adequate decontamination from zirconium. Addition of a small amount of fluoride was effective in maintaining adequate zirconium decontamination when neptunium recovery was increased by increasing the nitric acid concentration or by decreasing the uranium concentration.
\end{abstract}




\section{TABLE OF CONTENTS}

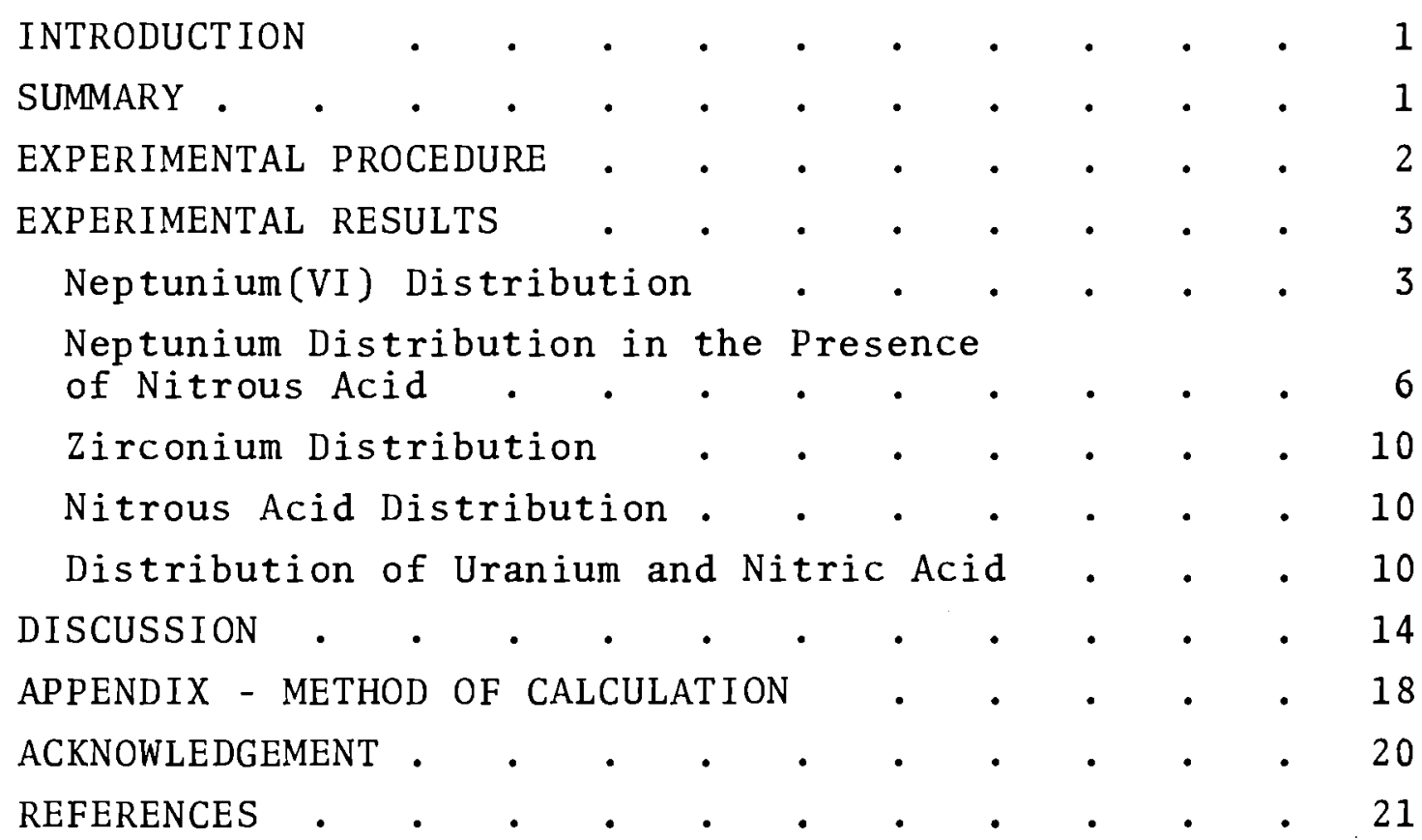




\section{LIST OF TABLES}

1 Neptunium(VI) Distribution 4

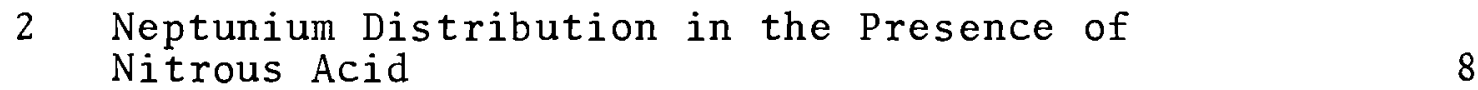

3 Zirconium Distribution 11

4 Distribution of $\mathrm{U}$ and $\mathrm{HNO}_{3} \quad 14$

5 Summary of the Effects of the Variables 16

\section{LIST OF FIGURES}

1 Neptunium(VI) Distribution 5

2 Neptunium Distribution 9

3 Zirconium Distribution $\quad 12$

4 Distribution of $\mathrm{HNO}_{2} \quad 13$

5 Effects of Variables on Neptunium Distribution 17 


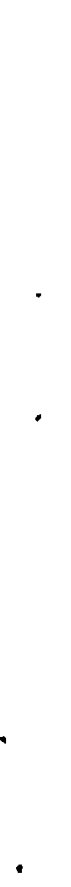




\section{INTRODUCTION}

In the Hanford Purex plant, neptunium is co-extracted with uranium and plutonium in the first solvent extraction column (the HA column). In earlier work ${ }^{(1)}$ factors affecting the rate of oxidation of inextractable neptunium(V) to extractable neptunium(VI) in the extraction section of this column were investigated. Other work ${ }^{(2)}$ showed that addition of small amounts of fluoride to the scrub stream would improve the decontamination from zirconium (the fission product element that generally limits decontamination in the Purex process). The present work was aimed at defining scrub section conditions that would maximize neptunium recovery while maintaining adequate decontamination from zirconium.

\section{SUMMARY}

Neptunium and zirconium distribution coefficients were measured under conditions typical of those in the scrub section of the HA column. Distribution data for nitrous acid, nitric acid, and uranium(VI) were also obtained. Valuable data were obtained under equilibrium conditions but attempts to obtain data concerning the rate of shifting of the equilibrium involving neptunium(V) and (VI) and nitric and nitrous acids were unsuccess ful.

Using the equilibrium data determined here and rate data determined earlier, neptunium distribution data were calculated for a variety of conditions. Variables of importance in maintaining high neptunium distribution through the scrub section are nitric acid concentration, uranium concentration, and nitrous acid concentration, in decreasing order of importance.

The distribution of neptunium was not affected by adding fluoride in an amount sufficient to give a significant 
reduction in the distribution of zirconium. Fluoride addition thus allows conditions to be adjusted to improve neptunium recovery without decreasing the decontamination from zirconium.

\section{EXPERIMENTAL PROCEDURE}

The solvent extraction contacts were performed at about $45^{\circ} \mathrm{C}$. The phases were brought to temperature separately, then combined and mixed for at least five minutes. Most of the contacts were performed in capped vials with mixing accomplished by magnetic stirring.

Zirconium and neptunium distribution coefficients (the concentration in the organic phase divided by that in the aqueous) were determined using ${ }^{95} \mathrm{Zr}$ and ${ }^{239} \mathrm{~Np}$ tracers. The lithiumdrifted germanium diode detector employed in the counting allowed the ${ }^{95} \mathrm{Zr}$ activity to be determined without interference from ${ }^{95} \mathrm{Nb}$. The zirconium and neptunium values were measured in separate experiments since the dichromate added to form neptunium(VI) was found to increase the zirconium distribution. Zirconium and neptunium concentrations of $10^{-5} \underline{M}$ were used as a precaution against effects that might arise from the presence of low concentrations of impurities. This concentration was maintained by the addition of ${ }^{237} \mathrm{~Np}$ or inactive zirconyl nitrate.

The ${ }^{95} \mathrm{Zr}$ tracer was extracted from a solution prepared by dissolving irradiated $\mathrm{UO}_{2}-\mathrm{PuO}_{2}$, then scrubbed into an aqueous phase which was then washed with dodecane to remove dissolved TBP. With this tracer, distribution coefficients were the same when organic phases containing extracted zirconium were scrubbed with fresh aqueous phases as when the zirconium was initially extracted.

The ${ }^{239} \mathrm{~Np}$ tracer was obtained as a solution of neptunium (IV). Various treatments were employed to obtain exchange with 
the ${ }^{237} \mathrm{~Np}$, which was added as neptunium(V). These included dichromate oxidation, nitrite oxidation, and nitrate oxidation on evaporation to dryness.

The solvent used in this work was tributyl phosphate (TBP) in normal paraffin hydrocarbon (NPH) diluent obtained from the Hanford Purex plant. The TBP concentration was adjusted to $30.0 \%$ from the as-received value of $31.7 \%$ (3) by dilution with dodecane. The solvent was washed with carbonate solution prior to use.

Nitric acid concentrations were determined by titration and uranium concentrations were determined spectrophotometrically, using prepared plots of absorbance versus uranium(VI) concentration at different nitric acid concentrations.

Nitrous acid concentrations were also determined spectrophotometrically. Prior to determination of $\mathrm{HNO}_{2}$ in the organic phase, most of the uranium was stripped out with $1: 1 \mathrm{H}_{3} \mathrm{PO}_{4}$ to avoid interference. In the nitrous acid distribution experiments, the concentration was determined in both phases. In the neptunium experiments the organic-phase $\mathrm{HNO}_{2}$ concentration was measured and the aqueous-phase concentration was calculated using the measured distribution coefficient.

\section{EXPERIMENTAL RESULTS}

\section{NEPTUNIUM(VI) DISTRIBUTION}

Neptunium(VI) distribution coefficients are listed in Table 1 and are plotted in Figure 1 . These data were obtained by extracting neptunium from solutions containing $0.01 \mathrm{M}$ $\mathrm{Na}_{2} \mathrm{Cr}_{2} \mathrm{O}_{7}$ to form neptunium(VI) and then measuring the distribution coefficients when the organic phases were scrubbed 
with fresh aqueous solutions. The scrub solution compositions were such that no changes in composition of the organic phases occured. Distribution coefficients measured in the extraction steps were sometimes lower than these values, possibly due to incomplete oxidation of the neptunium. These contacts were performed in capped vials in the dark.

TABLE 1. Neptunium(VI) Distribution $\sim 45^{\circ} \mathrm{C}$

\begin{tabular}{|c|c|c|c|}
\hline $\begin{array}{l}\text { Uranium in } \\
\text { Organic, } \underline{\underline{M}}\end{array}$ & $\begin{array}{c}\mathrm{HNO}_{3} \text { in } \\
\text { Aqueous, } \underline{\underline{M}}\end{array}$ & $\begin{array}{l}\text { Fluoride in } \\
\text { Aqueous, } \underline{\underline{M}}\end{array}$ & $D_{N p}(V I)$ \\
\hline \multirow[t]{3}{*}{0.25} & 1.9 & - & 2.71 \\
\hline & $\begin{array}{l}2.8 \\
2.8\end{array}$ & $0 . \overline{0} 1$ & $\begin{array}{l}3.31 \\
3.20\end{array}$ \\
\hline & 3.8 & - & $3.88,4.22$ \\
\hline \multirow[t]{3}{*}{0.30} & 1.9 & - & $2.05,2.11$ \\
\hline & $\begin{array}{l}2.9 \\
2.9\end{array}$ & $0 . \overline{01}$ & $\begin{array}{l}2.90,3.00,2.84 \\
2.90\end{array}$ \\
\hline & $\begin{array}{l}3.9 \\
3.9\end{array}$ & $0 . \overline{0} 1$ & $\begin{array}{l}2.84,3.14 \\
3.06\end{array}$ \\
\hline \multirow[t]{2}{*}{0.35} & 2.7 & - & 1.74 \\
\hline & 3.9 & - & 2.07 \\
\hline
\end{tabular}

These data show neptunium(VI) distribution increased with increasing nitric acid concentration and with decreasing organicphase uranium concentration, as expected. These effects were not especially large; the maximum variation over the ranges studied was only a factor of about four.

The effect of $0.01 \mathrm{M}$ fluoride on neptunium(VI) distribution was negligible. These data are included in Table 1.

Agreement of these data with similar data measured at room temperature ${ }^{(4)}$ is good at the lower nitric acid concentrations 


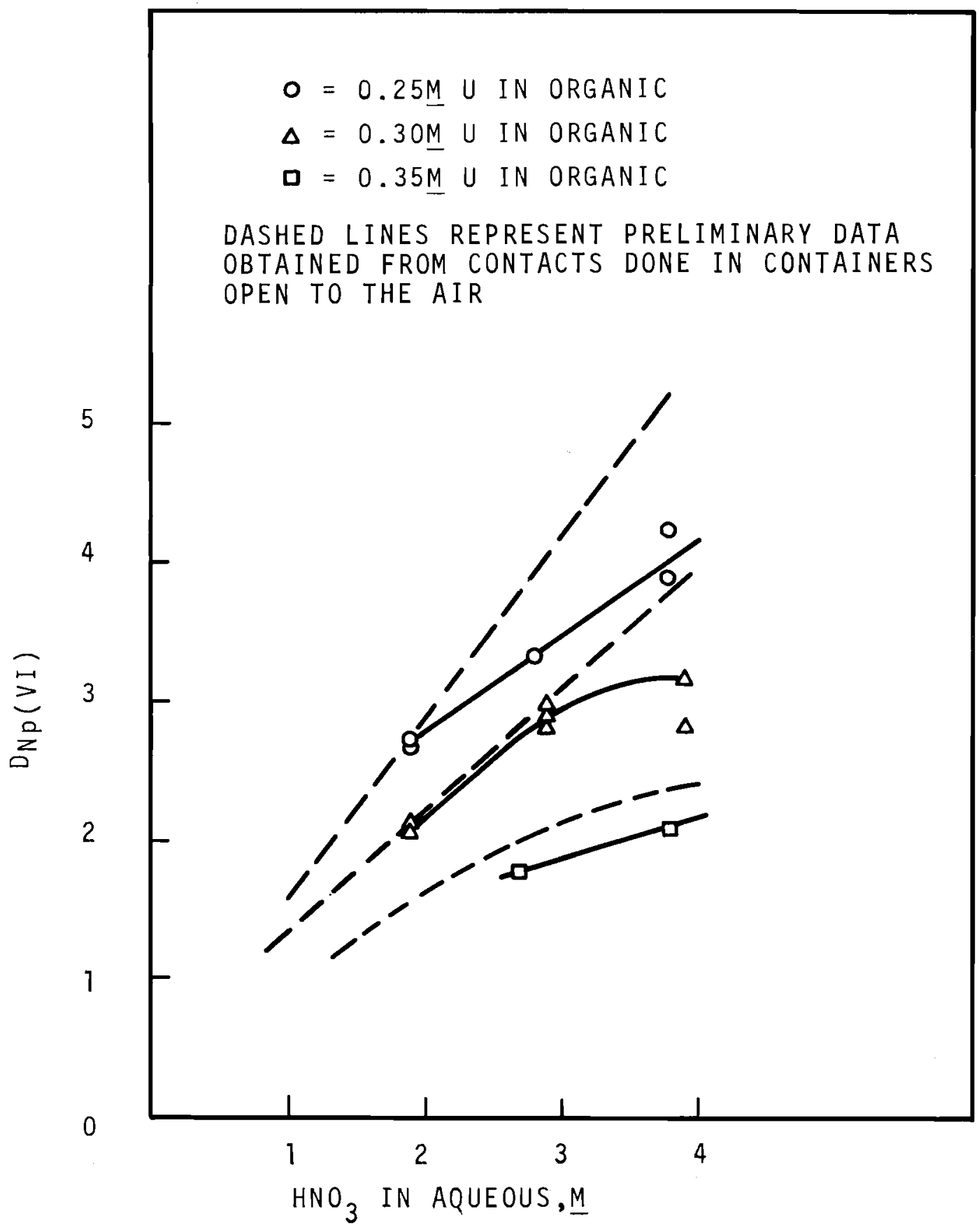

FIGURE 1. Neptunium (VI) Distribution 
but poor at the higher nitric acid concentrations. The room temperature data are higher than these data at the higher acid concentrations.

In the early stages of this work, extraction contacts were performed in open tubes exposed to light. These contacts gave higher neptunium(VI) distribution coefficients at high nitric acid concentrations than those measured in closed vials in the dark. These data fall along the dashed lines in Figure 1 . It is probable that these high results were caused by solvent degradation products resulting from the combined actions of oxygen, dichromate, and nitric acid.

NEPTUNIUM DISTRIBUTION IN THE PRESENCE OF NITROUS ACID

In aqueous nitric acid solutions containing nitrous acid, neptunyl species are in equilibrium according to the equation

$$
\mathrm{NpO}_{2}^{+}+3 / 2 \mathrm{H}^{+}+1 / 2 \mathrm{NO}_{3}^{-}=\mathrm{NpO}_{2}^{++}+1 / 2 \mathrm{HNO}_{2}+1 / 2 \mathrm{H}_{2} \mathrm{O} \text {. }
$$

Thus, when an organic phase containing neptunium(VI) and $\mathrm{HNO}_{2}$ is contacted with a fresh aqueous solution, portions of the neptunium and $\mathrm{HNO}_{2}$ will rapidly transfer to the aqueous phase and reduction of the neptunium(VI) will proceed until the equilibrium position is reached. Shifts in this equilibrium occur relatively slowly so that the relative amounts of neptunium(V) and (VI) present at a given time depend not only on the equilibrium position but also on the initial conditions and the time period in which reaction can occur. The kinetics of this reaction were first investigated by Siddall and Dukes (5) using solvent extraction techniques and more recently by this author (1) using spectrophotometric measurements in aqueous phase experiments. The results of these two studies were not in agreement; it was hoped that the present work would aid in resolving the disagreement. 
Results of experiments in which organic phases containing neptunium(VI) were contacted with aqueous phases containing $\mathrm{HNO}_{2}$ are presented in Table 2. Also presented are the results expected from the rate data determined earlier in this 1aboratory $(1)$ and the equilibrium quotient for reaction (1) and the neptunium(VI) distribution coefficients determined in the present work (assuming neptunium(V) to be completely inextractable). The equilibrium quotient determined here (from the data obtained in 1 ong term contacts) was about $50 \%$ higher than that determined earlier (1) (0.0006 versus 0.00038). The quotient was calculated using a third power dependence on $\mathrm{HNO}_{3}$ concentration, as was found in the earlier work.

The experimental results were quite inconsistent, sometimes lower than expected and other times higher. No explanation for this can be offered. It is obvious that no meaningful rate constant can be determined from these data. Also, no support for the correctness of either of the earlier kinetic studies can be drawn from these data.

While the kinetic data appear to be worthless, the equilibrium data are of value. They allow calculation of how far reaction (1) can shift under a given set of conditions, even though the rapidity of the shift may be uncertain. Distribution data for neptunium in equilibrium with $\mathrm{HNO}_{2}$ are compared with those for neptunium(VI) in Figure 2. Extrapolations based on calculated values are also shown. This figure emphasizes the fact that $\mathrm{HNO}_{2}$ can lower neptunium distribution less at high acidities than it can at low acidities, making the nitric acid concentration the most important variable affecting the distribution of neptunium in equilibrium with $\mathrm{HNO}_{2}$. 
BNWL - 1588

TABIE 2. Neptunium Distribution in the Presence of Nitrous Acid

$$
\begin{gathered}
0.3 \mathrm{M} \mathrm{U} \text { in Organic } \\
\sim 45^{\circ} \mathrm{C}
\end{gathered}
$$

[HNO 2$]$ in Aque ous

Time

Contacted Measured

$\frac{\text { Expected* } \mathrm{D}_{\mathrm{Np}}}{\text { After Time }}$

$(\mathrm{M} \times 104)$ (min)

$\mathrm{D}_{\mathrm{Np}}$

Contacted.

Equilibrium

With 1.9M HNO 3 in Aqueous $\left(D_{N p}(V I)=2.0\right)$

$\begin{array}{rllll}2.9 & 65 & 0.44 & & 0.39 \\ 3.5 & 10 & 0.53 & 0.76 & 0.36 \\ 3.8 & 20 & 0.38 & 0.47 & 0.35 \\ 3.8 & 30 & 0.57 & 0.39 & 0.35 \\ 4.0 & 10 & 0.60 & 0.68 & 0.34 \\ 4.5 & 10 & 1.50 & 0.62 & 0.33 \\ 10.0 & 10 & 0.34 & 0.29 & 0.23 \\ 10.7 & 60 & 0.27 & & 0.23 \\ 11.3 & 30 & 0.25 & & 0.22\end{array}$

With 2.9 $\underline{\mathrm{M}} \mathrm{HNO}_{3}$ in Aqueous $\left(\mathrm{D}_{\mathrm{Np}}(\mathrm{VI})=2.9\right)$

3.1

3.1

4.1

4.5

5.8

5.9

6.1

7.2

9.1

10.0

5

10

10

60

5

10

5

60

40

30
0.73

1.09

2.41

1.06

2.01

0.90

2.71

1.01

0.92

0.97
2.19

1.85

1.62

1.70

1.34

1.67

1.32

1.32

1.22

1.18

1.09

1.09

1.08

1.02

0.95

0.92

* Calculated as described in Appendix 


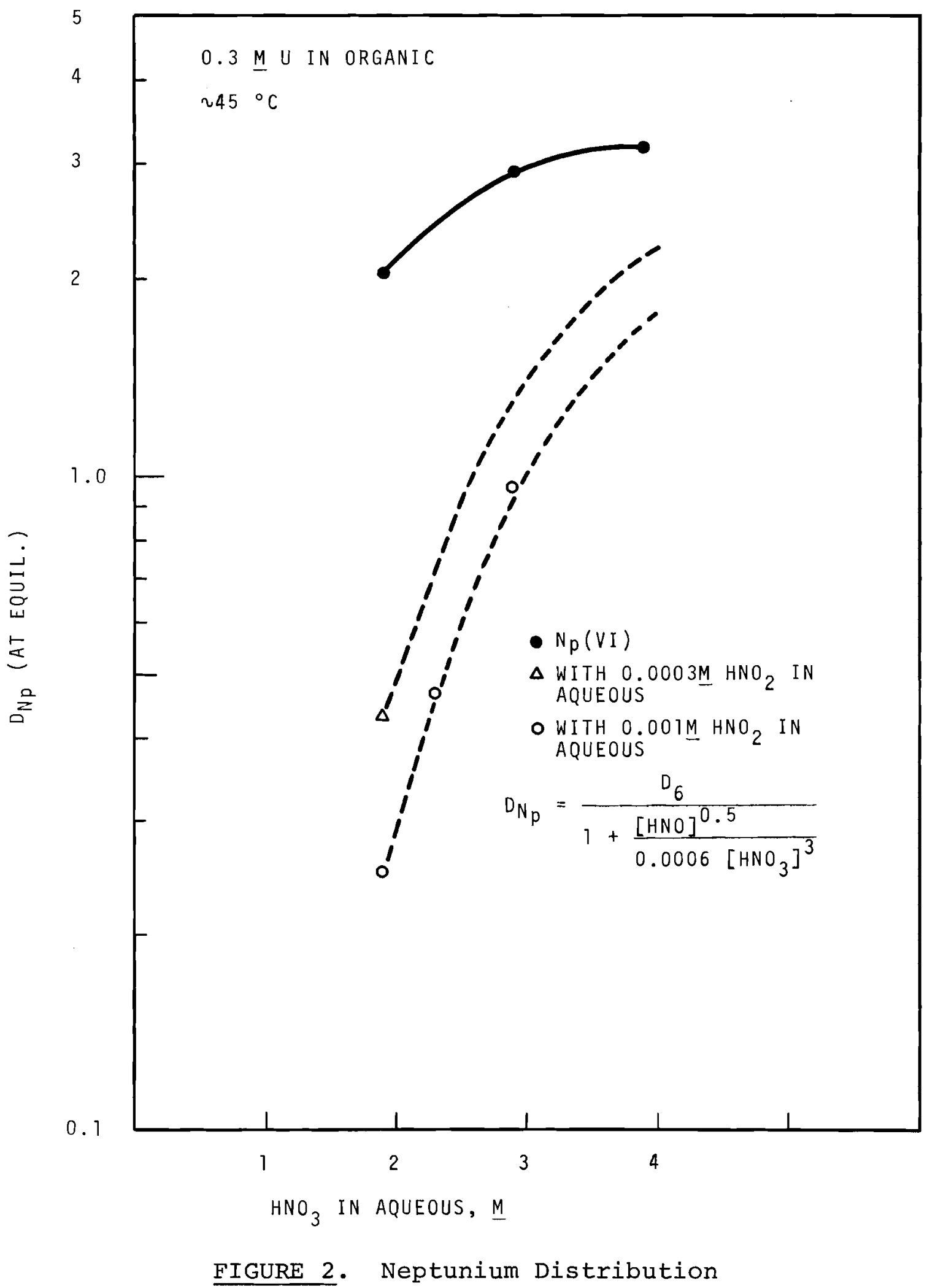


BNWL - 1588

\section{ZIRCONIUM DISTRIBUTION}

Data illustrating the effects of organic-phase uranium concentration and aqueous-phase nitric acid and fluoride concentrations on zirconium distribution are given in Table 3 and Figure 3. The effect of increasing the organic-phase uranium concentration from 0.25 to $0.35 \mathrm{M}$ was relatively minor. The effect of increasing the aqueous-phase nitric acid concentration was very pronounced, the zirconium distribution increasing approximately with the nitric acid concentration to the 2.5 power in the absence of fluoride. The effect of fluoride was to lower the zirconium distribution; this effect increased with increasing nitric acid concentration.

\section{NITROUS ACID DISTRIBUTION}

Because nitrous acid plays an important role in neptunium chemistry, its distribution was measured. The distribution decreased with increasing nitric acid concentration and varied little if at all with organic-phase uranium concentration. These data are shown in Figure 4.

\section{DISTRIBUTION OF URANIUM AND NITRIC ACID}

Experimental conditions were chosen to give data at three different organic-phase uranium concentrations at various aqueous-phase nitric acid concentrations. The conditions used were chosen from concentration profiles calculated using the computer program SEPHIS as revised by G. L. Richardson. (6) Good agreement between the calculated and measured values was obtained where comparison was made. Table 4 contains a listing of the conditions used and the comparative data obtained. 
TABLE 3. Zirconium Distribution

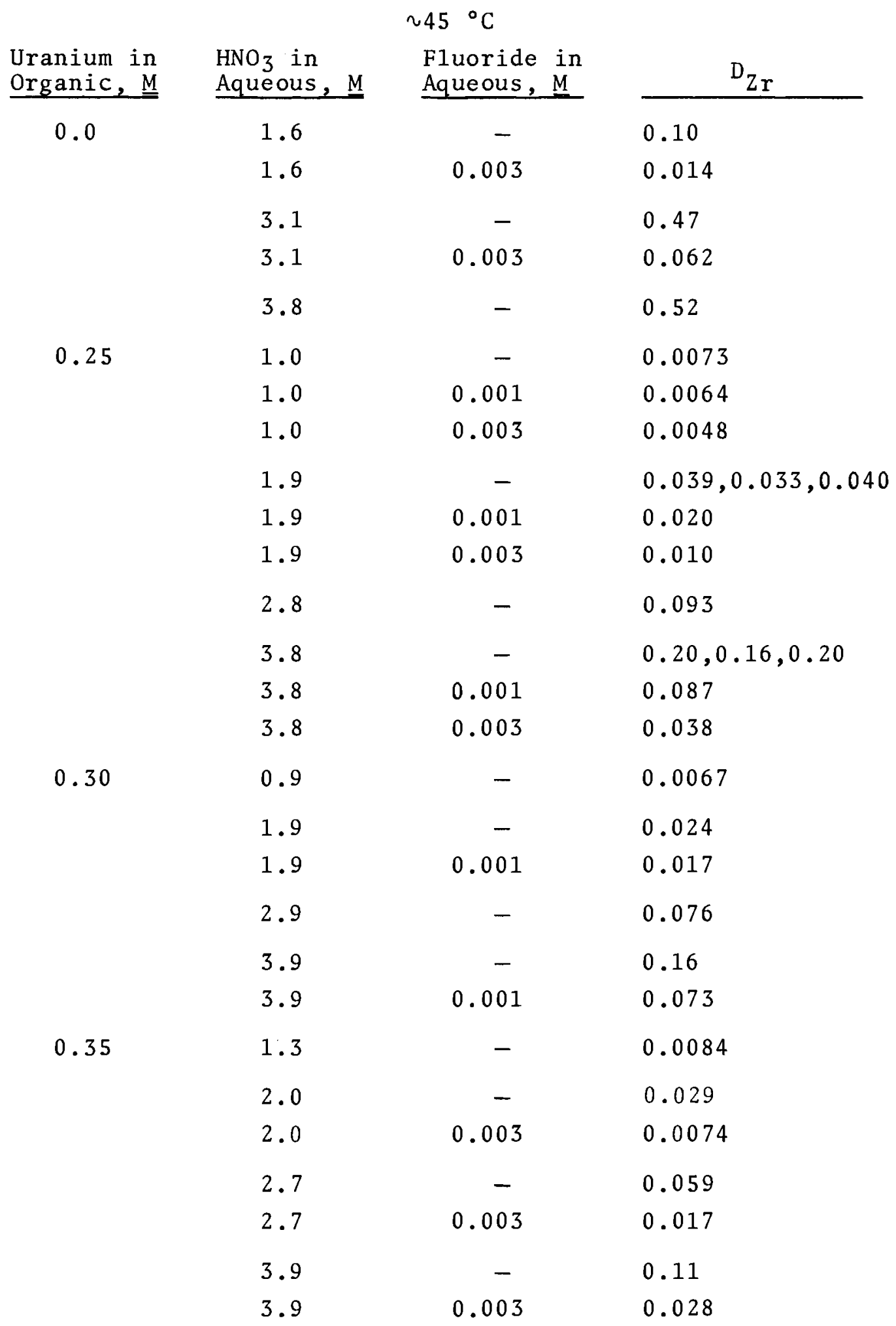




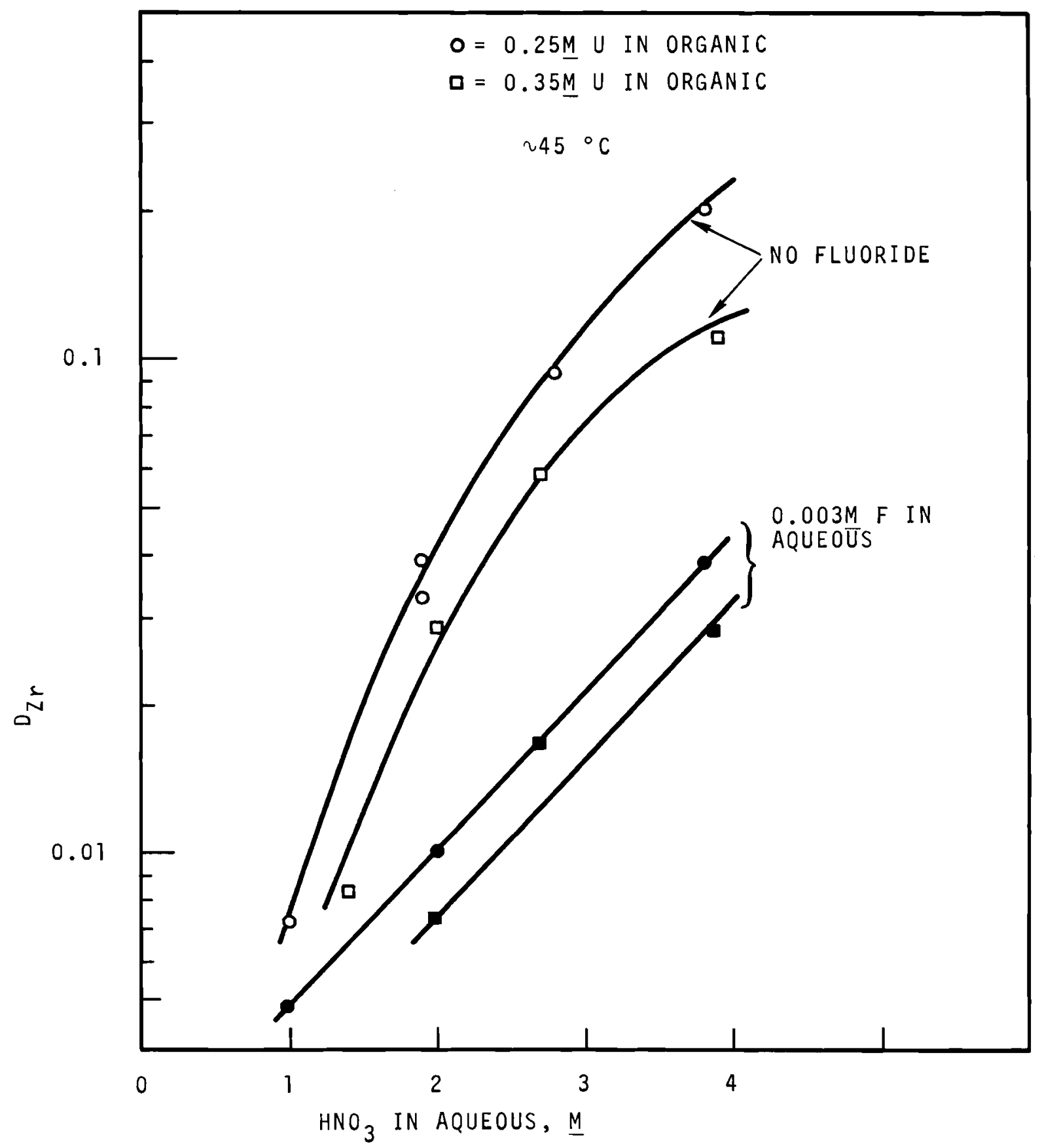

FIGURE 3. Zirconium Distribution 


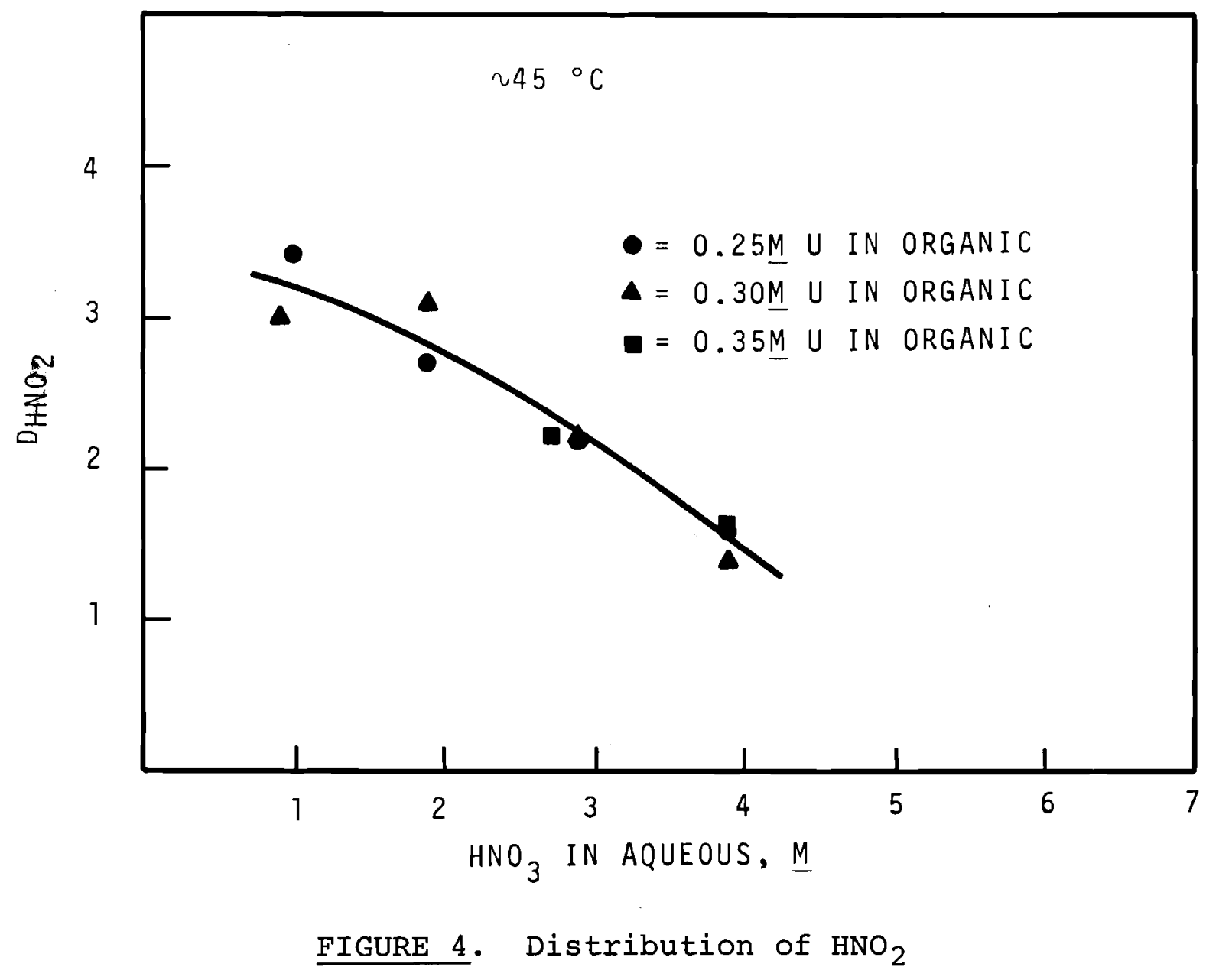


TABLE 4. Distribution of $\mathrm{U}$ and $\mathrm{HNO}_{3}$ $\sim 45{ }^{\circ} \mathrm{C}$

\begin{tabular}{|c|c|c|c|c|c|c|c|}
\hline \multicolumn{4}{|c|}{ Calculated $^{(1)}$} & \multicolumn{4}{|c|}{ Measured ${ }^{(2)}$} \\
\hline$\frac{\text { Urani }}{\text { Organic }}$ & $\frac{\text { um, }, \underline{M}}{\text { Aque ous }}$ & $\frac{\mathrm{HNO}_{3}^{-}}{\text {Organic }}$ & $\frac{\frac{M}{-}}{\text { Aque ous }}$ & $\frac{\text { Urani }}{\text { Organic }}$ & $\frac{\mathrm{m}, \mathrm{M}}{\text { Aqueous }}$ & $\frac{\mathrm{HNC}}{\text { Organic }}$ & $\frac{M}{\text { Aque ous }}$ \\
\hline 0.25 & 0.10 & 0.10 & 1.0 & $(0.24)$ & 0.11 & $(0.1)$ & 1.0 \\
\hline 0.25 & 0.051 & 0.22 & 1.9 & $(0.24)$ & 0.056 & $(0.2)$ & 1.95 \\
\hline 0.25 & 0.032 & 0.34 & 2.8 & $(0.24)$ & 0.037 & $(0.2)$ & 2.9 \\
\hline 0.25 & 0.026 & 0.44 & 3.85 & & & & \\
\hline 0.30 & 0.17 & 0.08 & 0.9 & $(0.31)$ & 0.16 & $(0.0)$ & 1.0 \\
\hline 0.30 & 0.082 & 0.18 & 1.9 & 0.30 & 0.084 & $(0.2)$ & 2.0 \\
\hline 0.30 & 0.050 & 0.29 & 2.9 & & & & \\
\hline 0.30 & 0.043 & 0.37 & 3.9 & $(0.30)$ & 0.041 & $(0.4)$ & 3.9 \\
\hline 0.35 & 0.20 & 0.10 & 1.3 & & & & \\
\hline 0.36 & 0.14 & 0.15 & 2.0 & & & & \\
\hline 0.35 & 0.10 & 0.22 & 2.7 & & & & \\
\hline 0.34 & 0.069 & 0.30 & 3.9 & & & & \\
\hline
\end{tabular}

(1) Calculated by program SEPHIS (G. L. Richardson revised version)

(2) Values in parenthesis obtained by difference

\section{DISCUSSION}

In the scrub section of the HA column, the organic phase containing neptunium(VI) is contacted with an aqueous phase which contains uranium, nitric acid, nitrous acid, neptunium(VI) and neptunium(V) in amounts which vary down the column. It would be difficult to calculate the neptunium profile under these conditions even if the reaction

$$
\mathrm{NpO}_{2}^{+}+3 / 2 \mathrm{H}^{+}+1 / 2 \mathrm{NO}_{3}^{-}=\mathrm{NpO}_{2}^{++}+1 / 2 \mathrm{HNO}_{2}+1 / 2 \mathrm{H}_{2} \mathrm{O}
$$


were rapid. With the rate of attainment of this equilibrium position being relatively slow, calculation of the neptunium profile becomes even more difficult.

The distribution data for nitrous acid and neptunium were used with the rate constant measured earlier ${ }^{(1)}$ in calculations to illustrate the effects of the variables on the neptunium distribution. Details of the method of calculation are given in the Appendix. The conditions chosen for the calculations are typical of those in the scrub section of the HA column, where the organic phase contains about $0.001 \mathrm{M} \mathrm{HNO}_{2}$ and the aqueous phase residence time is about two minutes per stage. (7) The results of these calculations are given in Table 5 and some are plotted in Figure 5.

The effects of the variables on the neptunium distribution can be summarized as:

- Neptunium distribution increases with increasing aqueousphase nitric acid concentration. The dependence becomes greater as the ratio of neptunium species approaches the equilibrium value.

- Neptunium distribution decreases with increasing organicphase uranium concentration. This dependence is about the same at equilibrium as it is at intermediate times.

- Neptunium distribution decreases with increasing organicphase nitrous acid concentration.

The separation of neptunium from zirconium is improved by the addition of fluoride. The data shown in Table 5 indicate that $0.003 \mathrm{M}$ fluoride improves the separation by a factor of four to five. The improvement achieved in the plant would probably be much greater than this because fluoride has been shown ${ }^{(2)}$ to reduce greatly the amount of the highly extractable zirconium species which normally limits the separation in the plant. 
TABLE 5. Summary of the Effects of the Variables (Calculated Results)

\begin{tabular}{|c|c|c|c|c|c|c|c|c|}
\hline \multirow{2}{*}{\multicolumn{2}{|c|}{ In Aqueous, $\mathrm{M}$}} & & & & \multicolumn{4}{|c|}{$\mathrm{D}_{\mathrm{Np}}{ }^{\mathrm{D}} \mathrm{Zr}$} \\
\hline & & \multicolumn{3}{|c|}{$\mathrm{D}_{\mathrm{Np}}$} & \multicolumn{2}{|c|}{ No Fluoride } & \multicolumn{2}{|c|}{$0.003 \mathrm{M} \mathrm{F}$} \\
\hline $\mathrm{HNO}_{3}$ & $\mathrm{HNO}_{2}$ & $\begin{array}{l}\text { Zero } \\
\text { Time } \\
\end{array}$ & $\begin{array}{l}\text { After } \\
2 \text { min } \\
\end{array}$ & $\begin{array}{c}\overline{A t} \\
\text { Equil }\end{array}$ & $\begin{array}{l}\overline{\text { After }} \\
2 \mathrm{~min} \\
\end{array}$ & $\begin{array}{c}\mathrm{At} \\
\text { Equil }\end{array}$ & $\begin{array}{l}\overline{\text { After }} \\
2 \mathrm{~min} \\
\end{array}$ & $\begin{array}{c}\mathrm{At} \\
\text { Equi } 1\end{array}$ \\
\hline \multicolumn{9}{|c|}{ With $0.25 \mathrm{M} \mathrm{U}+0.001 \underline{\mathrm{MNO}} 2$ in Organic } \\
\hline 1 & 0.00031 & 1.50 & 1.08 & 0.049 & 148 & 7 & 225 & 10 \\
\hline 2 & 0.00036 & 2.75 & 1.78 & 0.55 & 43 & 13 & 178 & 55 \\
\hline 3 & 0.00048 & 3.45 & & 1.47 & & & & \\
\hline 4 & 0.00069 & 4.15 & 3.50 & 2.47 & 15 & 11 & 80 & 56 \\
\hline \multicolumn{9}{|c|}{ With 0} \\
\hline 1 & 0.00062 & 1.50 & 0.81 & 0.035 & & & & \\
\hline 2 & 0.00072 & 2.75 & 1.49 & 0.42 & & & & \\
\hline 4 & 0.00138 & 4.15 & 2.88 & 2.12 & & & & \\
\hline With & $0.25 \mathrm{M} \mathrm{U}+$ & 0.005 & $1 \mathrm{HNO}_{2}$ & in Orga & $\mathrm{ic}$ & & & \\
\hline 1 & 0.00156 & 1.50 & & 0.022 & & & & \\
\hline 2 & 0.00182 & 2.75 & 0.74 & 0.28 & & & & \\
\hline 4 & 0.00345 & 4.15 & & 1.64 & & & & \\
\hline
\end{tabular}

With $0.30 \underline{\mathrm{M} U}+0.001 \underline{\mathrm{M}} \mathrm{HNO} 2$ in Organic

$\begin{array}{llll}2 & 0.00036 & 2.15 & 0.43 \\ 3 & 0.00048 & 2.95 & 1.26 \\ 4 & 0.00069 & 3.20 & 1.90\end{array}$

With $0.35 \underline{\mathrm{M} \mathrm{U}}+0.001 \underline{\mathrm{MNO}} 2$ in Organic

$\begin{array}{lllllllll}2 & 0.00036 & 1.55 & 1.20 & 0.31 & 44 & 11 & 162 & 42 \\ 3 & 0.00048 & 1.85 & & 0.79 & & & & \\ 4 & 0.00069 & 2.15 & & 1.28 & & 11 & & 40\end{array}$



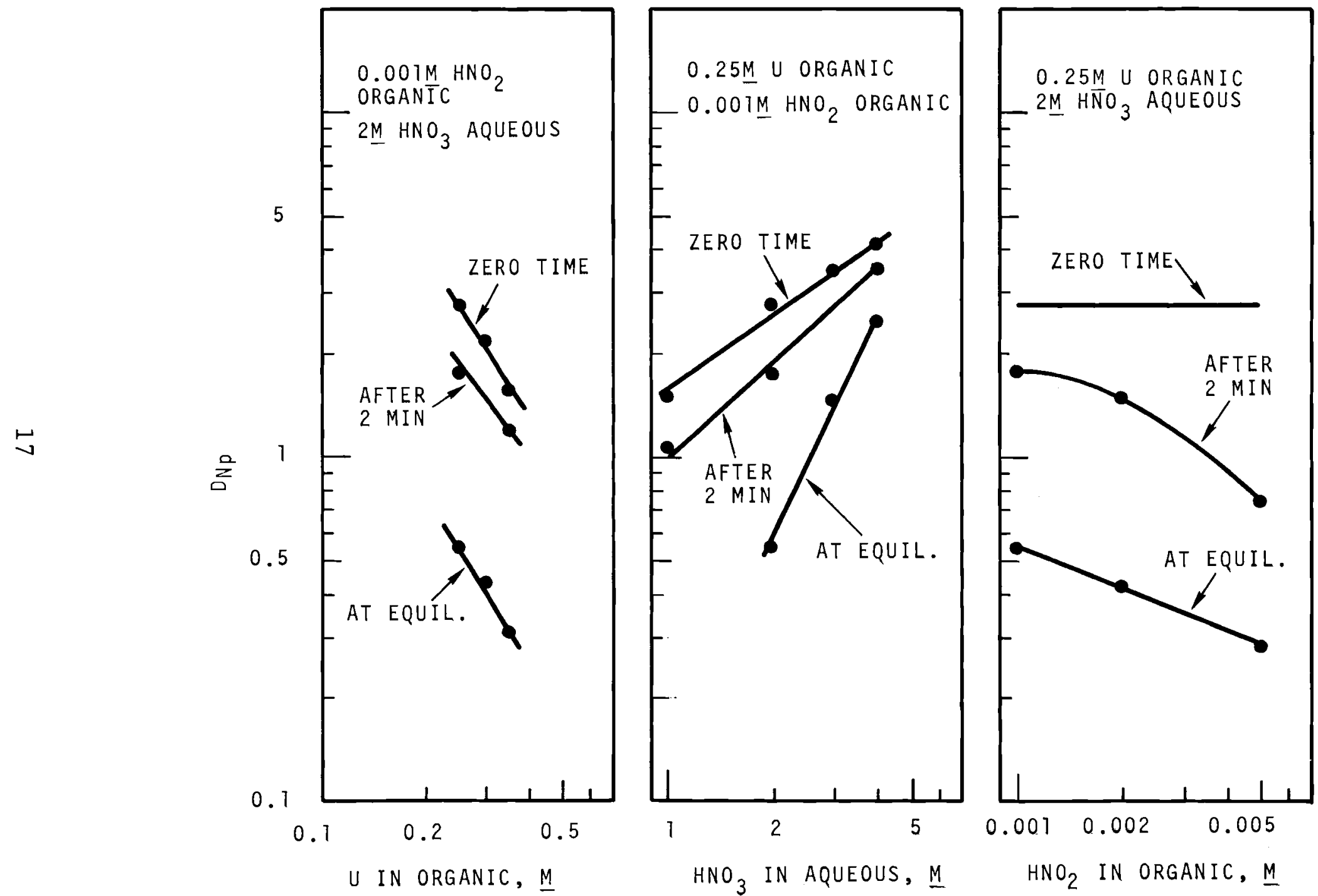

FIGURE 5. Effects of Variables on Neptunium Distribution 


\section{APPENDIX - METHOD OF CALCULATION}

\section{ASSUMPTIONS}

1. $N_{p}(V)$ is completely inextractable.

2. $\mathrm{N}_{\mathrm{p}}(\mathrm{VI})$ distribution occurs very rapidly.

3. Oxidation and reduction of neptunium species occur only in aqueous phase, and at rates determined in earlier work. (1)

\section{SYMBOLS}

$\mathrm{C}_{\mathrm{T}}=\operatorname{total} \mathrm{N}_{\mathrm{p}}$ concentration

$\mathrm{C}_{6, \text { org }}=$ concentration of $\mathrm{N}_{\mathrm{p}}(\mathrm{VI})$ in organic phase

$\mathrm{C}_{6, \mathrm{aq}}=$ concentration of $\mathrm{N}_{\mathrm{p}}(\mathrm{VI})$ in aqueous phase

$\mathrm{C}_{5}=$ concentration of $\mathrm{N}_{\mathrm{p}}(\mathrm{V})$ in aqueous phase

$\mathrm{D}_{6}=\mathrm{N}_{\mathrm{p}}(\mathrm{VI})$ distribution coefficient

$$
\begin{aligned}
& D_{6}=\frac{C_{6}, \text { org }}{C_{6}, a q} \\
& D_{N_{p}}=N_{p} \text { distribution coefficient } \\
& D_{N_{p}}=\frac{C_{6}, \text { org }}{C_{5}+C_{6}, a q}
\end{aligned}
$$

CALCULATION OF DNP WHEN NEPTUNIUM SPECIES ARE IN EQUILIBRIUM $\underline{\text { RATI I }}$

At equilibrium, $\frac{\mathrm{C}_{6}, \mathrm{aq}\left[\mathrm{HNO}_{2}\right]^{0.5}}{\mathrm{C}_{5}\left[\mathrm{HNO}_{3}\right]^{3}}=\mathrm{K}$.

Then $\mathrm{C}_{5}=\mathrm{C}_{6}$, aq $\frac{\left[\mathrm{HNO}_{2}\right]^{0.5}}{\mathrm{~K}\left[\mathrm{HNO}_{3}\right]^{3}}$,

and $D_{N_{p}}=\frac{C_{6}, \text { org }}{C_{6}, \mathrm{aq}^{+\mathrm{C}_{5}}}=\frac{\mathrm{C}_{6, \text { org }}}{\mathrm{C}_{6, \mathrm{aq}}+\mathrm{C}_{6}, \mathrm{aq} \frac{\left[\mathrm{HNO}_{2}\right]_{0.5}}{\mathrm{~K}\left[\mathrm{HNO}_{3}\right]^{3}}}$ 


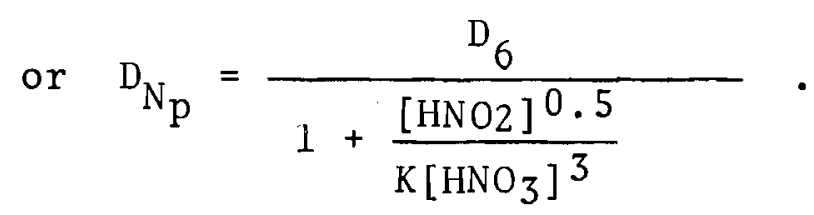

In this work, a value of 0.00060 was found for $K$ at $\sim 45^{\circ} \mathrm{C}$.

\section{CALCULATION OF DNP WHEN NEPTUNIUM SPECIES ARE NOT AT}

\section{EQUILIBRIUM}

When $\mathrm{C}_{5}=0$ at zero time (as when an organic phase containing $\mathrm{N}_{\mathrm{p}}(\mathrm{VI})$ is scrubbed with a fresh aqueous phase), $\mathrm{C}_{5}$ at time $t$ can be calculated from the time, the aqueous phase $\mathrm{HNO}_{2}$ concentration, and $\mathrm{C}_{5}$ at equilibrium (which is calculated from equation (1)):

$$
\ln \frac{\mathrm{C}_{5}, \mathrm{eq}}{\mathrm{C}_{5}, \mathrm{eq}^{-\mathrm{C}_{5}}}=\mathrm{k} \mathrm{t}\left[\mathrm{HNO}_{2}\right]_{\mathrm{aq}} \text {. }
$$

In earlier work, ${ }^{(1)} \mathrm{k}$ was found to have a value of about $250(\underline{M}, \mathrm{~min})^{-1}$ at $46^{\circ} \mathrm{C}$.

The value of $\mathrm{C}_{5}$ at time $t$ is then used to obtain the value of $\mathrm{C}_{6}$,org at time $t$ :

$$
\begin{aligned}
& C_{6, \text { org }}+C_{6, \text { aq }}=C_{T}-C_{5} \quad \text { (with equal phase volumes) } \\
& C_{6, \text { org }}+\frac{C_{6} \text {, org }}{D_{6}}=C_{T}-C_{5} \\
& C_{6, \text { org }}=\frac{C_{T}-C_{5}}{1+\frac{1}{D_{6}}} .
\end{aligned}
$$

The value of $\mathrm{C}_{6}$, org is then used to calculate $\mathrm{D}_{\mathrm{Np}}$ :

$$
\mathrm{D}_{\mathrm{N}_{\mathrm{p}}}=\frac{\mathrm{C}_{6, \text { org }}}{\mathrm{C}_{\mathrm{T}}-\mathrm{C}_{6, \text { org }}}
$$




\section{ACKNOWLEDGEMENT}

The assistance of Mrs. Doris Meier and Mrs. Thelma Lawell in performing the experimental work is gratefully acknowledged. Discussions with Mr. Glen Benedict of Atlantic Richfield Hanford Company were also very helpful. 


\section{REFERENCES}

1. J. L. Swanson. "Oxidation of Neptunium(V) in Nitric Aaid Solution - Laboratory Study of Rate Accelerating Materials (RAM)," BNWL-1017, 1969 .

2. J. L. Swanson. "Improved Zirconium Decontamination in Purex Process," BNWL-1573. 1971.

3. R. W. James, ARHCO, Personal Communication.

4. N. Srinivasan, et al. "Process Chemistry of Neptunium," $B A R C-428,1969$.

5. T. H. Siddall, III, and E. K. Dukes. "Kinetics of HNO, Catalyzed oxidation of Neptunium(V) by Aqueous Solutions of Nitric Acid," J. Am. Chem. Soc., vol. 81, p. 790. 1959.

6. G. L. Richardson, WADCO, Personal Communication.

7. R. L. Walser, ARHCO, Personal Communication. 

. 


\section{DISTRIBUTION}

No. of

Copies

OFFSITE

1

$\frac{\text { AEC Chicago Patent Group }}{\text { G. H. Lee }}$

194

AEC Division of Technical Information Extension

ONSITE-HANFORD

1 AEC Chicago Patent Group

R. M. Poteat

1 AEC Richland Operations Office

O. J. Elgert

R. K. Heusser

J. E. McDonald

M. R. Schne11er

2 RDT Assistant Director for Pacific Northwest Programs

$24 \quad$ ARHCO

G. E. Benedict

L. E. Bruns

M. H. Campbe 11

R. P. Corlew

J. B. Fecht

R. C. Forsman

W. L. Godfrey

D. G. Harlow

K. H. Henry

R. E. Isaacson

L. M. Knights

C. W. Malody

G. A. Nicholson

G. C. Oberg

R. A. Pease

L. M. Richards

R. C. Roal

W. W. Schulz 
No. of

Copies

$\underline{\text { ARHCO (contd) }}$

H. P. Shaw

P. W. Smith

M. J. Szulinski

R. E. Tomlinson

R. E. Vandercook

R. L. Walser

$27 \quad$ Batte11e-Northwest

J. M. Batch

L. A. Bray

L. L. Burger

R. E. Burns

R. E. Nightingale

J. L. Swans on (15)

Technical Information (5)

Technical Publications 